\title{
PROBING BARLEY MUTANTS WITH A MONOCLONAL ANTIBODY TO A POLYPEPTIDE INVOLVED IN PHOTOSYNTHETIC OXYGEN EVOLUTION
}

\author{
by \\ LISBETH SKOU HØNBERG \\ Department of Physiology, Carlsberg Laboratory, \\ Gamle Carlsberg Vej 10, DK-2500 Copenhagen Valby \\ and \\ Institute of Genetics, University of Copenhagen \\ Øster Farimagsgade 2A, DK-1353 Copenhagen K
}

Keywords: Hybridoma line, immune-blot assay, thylakoid polypeptides, barley, viridis- $z d^{69}$, viridis- $m^{29}$, viridis-115, tigrina-o ${ }^{34}$ internal etioplast membranes, water-splitting

A stable hybridoma line derived from the fusion of mouse myeloma cells with spleen cells from a mouse immunized with photosystem II vesicles has been isolated. The hybridoma cells secrete monoclonal antibodies to a $23 \mathrm{kD}$ polypeptide present in isolated barley wild-type thylakoid membranes and known to be involved in water-splitting activity of photosystem II. No reaction between this monoclonal antibody to the $23 \mathrm{kD}$ polypeptide and isolated internal etioplast membranes was detectable in immune-blot assays indicating that the synthesis of this polypeptide is stimulated by light. Immune-blots also revealed that the amount of $23 \mathrm{kD}$ polypeptide in the photosystem II deficient mutants viridis- $z d^{69}$, viridis $-m^{29}$ and viridis-115 is the same as in the wild-type. This indicates either that the oxygen evolving complex, of which the $23 \mathrm{kD}$ polypeptide is a component, can be assembled independently of the photosystem II reaction centre, or that the $23 \mathrm{kD}$ polypeptide, in the absence of the photosystem II reaction centre, is located in the thylakoid lumen and protected from protease attack. Furthermore it was shown that the cold sensitive barley mutant tigrina $-0^{34}$ contained the $23 \mathrm{kD}$ polypeptide whether grown at $23^{\circ} \mathrm{C}$ or $30^{\circ} \mathrm{C}$. The amount, on a chlorophyll basis, was reduced compared to that in the wild-type. Since the 23 $\mathrm{kD}$ polypeptide is present in tigrina- $0^{34}$ plants grown at $23{ }^{\circ} \mathrm{C}$ which lack chloroplast ribosomes, the $23 \mathrm{kD}$ polypeptide must be coded for by a gene in the nucleus.

\footnotetext{
Abbreviations: $\mathrm{BSA}=$ bovine serum albumin; DMEM = Dulbecco's modified Eagles' medium; DMSO = dimethylsulphoxide; DTT = dithiothreitol; EDT A = ethylenediamine tetraacetate; EFs = endoplasmatic fracture face (stacked); ELISA = enzyme linked immunosorbent assay; ESs = endoplasmatic surface of stacked thylakoids; FCA = Freund's complete adjuvant; FiCA = Freund's incomplete adjuvant; Hepes = N-2-hydroxyethylpiperazine$\mathrm{N}$ '-2-ethane sulphonic acid; $\mathrm{Ig}=$ immunoglobulin; $\mathrm{kD}=$ kilodalton; $\mathrm{Mr}=$ molecular weight; $\mathrm{NBC}=$ newborn calf serum; PBS = phosphate buffered saline; PFs = protoplasmatic fracture face (stacked); PS I = Photosystem I; PS II $=$ Photosystem II; SDS-PAGE = sodium dodecyl sulphate polyacrylamide gel electrophoresis; Tricine $=$ $\mathrm{N}$-(tris(hydroxymethyl)methyl)-glycine; $\mathrm{Wt}=$ wild-type.
} 


\section{INTRODUCTION}

The functional identification of various thylakoid membrane polypeptides has been achieved by correlating mutant polypeptide patterns with photosynthetic defects $(7,13,23,24,29)$. Another successful approach has been the study of preparations of membrane vesicles enriched in either PS I or PS II activity $(4,12,27,28)$. Progress has been made in identifying the proteins involved in oxygen evolution of photosystem II. ÁKERLUND et al. (1) report that four polypeptides of $M_{r} 34,000,23,000,21,000$ and 16,000 can be released from inside-out PS II vesicles by high salt washing, resulting in an inhibition of oxygen evolution. Readdition of the four polypeptides to the washed inside-out vesicles resulted in partial reconstitution of oxygen evolution (1). MøLLER and HøJ (27) were able to release three polypeptides of $\mathrm{M}_{\mathrm{r}} 32,000$, 23,000 and 13,500 by high salt treatment of inside-out vesicles or a photosystem II preparation obtained with Triton X-100. The three polypeptides have been purified to homogeneity by chromatofocusing. Reconstitution of photosynthetic oxygen evolution was achieved by adding the purified 23,000 polypeptide to the salt washed photosystem II vesicles depleted of the $32,000,23,000$ and 13,500 molecular weight polypeptides. Reconstitution was not seen when the 32,000 or 13,500 polypeptides were added to the depleted membranes. Recently, a role for the $23 \mathrm{kD}$ polypeptide in modifying the chloride requirement of oxygen evolution has been proposed (2).

Monoclonal antibodies $(10,21,26)$ would appear to be excellent tools to extend such studies - specifically to determine the presence of polypeptides in photosynthetic mutants and the site of synthesis of the proteins involved in photosynthesis. Two major advantages of the technique are that purification of the antigen prior to immunization is not neccessary, and the antibody obtained is monospecific.

In this study mice were immunized with a preparation of PS II vesicles (27), which contained a minimum of 10 polypeptides. By fusing mouse myeloma cells with spleen cells from an immunized mouse, a hybridoma line was obtained that secreted antibodies to a $23 \mathrm{kD}$ polypeptide (15). This monoclonal antibody has been used to determine the site of synthesis of the $23 \mathrm{kD}$ polypeptide in the cold-sensitive mutant tigrina- $^{34}$ (17). In addition, the occurrence of the $23 \mathrm{kD}$ polypeptide in etioplast membranes and three PS II mutants viridis- $z d^{69}$, viridis- $m^{29}$ and viridis-115 was determined.

\section{MATERIALS AND METHODS}

\subsection{Plant material}

Seeds of wild-type barley (Hordeum vulgare cv. Svalof's Bonus) and the mutants tigrina- $o^{34}$, $(5,17,18,30)$, viridis-zd $d^{69},(23,24,38,43)$, viridis- $m^{29}(18,24,43)$ and viridis-115 (18) were germinated in tap water moistened vermiculite. For the isolation of thylakoids from wild-type and mutants, seeds were grown under standard conditions in continuous white light ( $1,700 \mathrm{lux})$ at $23^{\circ} \mathrm{C}$ and harvested after seven days. Additionally, seeds from wild-type and tigrina- $0^{34}$ were grown in continuous light at $30^{\circ} \mathrm{C}$. These seedlings were harvested after six days growth to achieve a comparable stage of development. Etioplasts were isolated from wild-type seeds grown in complete darkness for seven days at 23 ${ }^{\circ} \mathrm{C}$.

\subsection{Chemicals, culture media and cells}

Myeloma cells (Sp 2/0- Ag 14) (36) were kindly provided by Dr. G. KOHLER (Basel Institute for Immunology).

Myeloma and hybridoma cells were cultured in Dulbecco's modified Eagles' medium (DMEM) obtained from Flow Laboratories, Irvine, Scotland, supplemented with $2 \mathrm{mM}-\mathrm{L}$ glutamine (Sigma Chemical Company, St. Louis, Mo., U.S.A.), 1 mM-sodium pyruvate (Boehringer, Mannheim, W. Germany), 100 units/ml penicillin-streptomycin solution (Gibco, Paisley, Scotland), 0,05 mm-2-mercaptoethanol (Merck, Darmstatt, W. Germany) and $10 \%(\mathrm{v} / \mathrm{v})$ fetal calf serum (Gibco). This supplemented DMEM is called complete DMEM.

Hybridoma cells were selected in complete DMEM further supplemented with $1 \%(\mathrm{v} / \mathrm{v})$ stock solution of $10 \mathrm{~mm}$-hypoxanthine, 1.6 mM-thymidine and $0.04 \mathrm{~mm}$-aminopterine. These chemicals were obtained from Sigma. This selective medium is called HAT medium. 
The cells were frozen in $10 \%(\mathrm{v} / \mathrm{v})$ dimethylsulphoxide (DMSO) purchased from Merck in complete DMEM.

Goat anti-mouse immunoglobulin $\mathbf{G}$ and $\mathbf{M}$ (IgG, IgM) were obtained from Meloy Laboratories, Inc., Diagnostics Division, Springfield, (USA). Peroxidase-conjugated rabbit antimouse immunoglobulin was a product of DAKO-immunoglobulins a/s Denmark. N-2hydroxy-ethylpiperazine-N'-2-ethanesulphonic acid (Hepes), dithiothreitol (DTT), N-(Tris(hydroxy-methyl)-methyl)-glycine (tricine) and 3amino-9-ethylcarbazole were purchased from Sigma. Newborn calf serum (NBC) was supplied by Gibco. Bovine serum albumin (BSA) was obtained from Fluka AG, Switzerland. SephacrylS-300 was purchased from Pharmacia, Uppsala, Sweden. For biosynthetic labelling $\mathrm{L}-{ }^{35} \mathrm{~S}-$ methionine (specific activity approx. 1470 $\mathrm{Ci} \cdot \mathrm{mmol}^{-1}$ ) was obtained from Amersham International, U.K. X-ray film (X-Omat RP 1) was from Kodak (USA). For immune-blot assays nitrocellulose filter (HAHY pore size $0.45 \mu \mathrm{m}$ ) was purchased from Millipore S.A. Molsheim, France.

Phosphate buffered saline (PBS) at $\mathrm{pH} 7.2$ was prepared from $10 \mathrm{mM}$-phosphate and $140 \mathrm{mM}$ $\mathrm{NaCl}$. Ethylenediamine tetraacetate (EDTA) and trichloroacetic acid were obtained from Merck. Freund's complete and incomplete adjuvant (FCA and FiCA) were products of Difco Laboratories, Detroit, Michigan, USA.

Isolated PS II vesicles and purified $23 \mathrm{kD}$ polypeptide were kindly supplied by Dr. B. LiNDberG Møller and P.B. HøJ, Carlsberg Laboratory, Copenhagen, Denmark.

\subsection{Isolation of purified thylakoids and etioplasts}

The isolation of barley thylakoids and etioplasts was performed according to published procedures (19), except that the isolation buffer contained $0.4 \mathrm{M}$-sucrose, $50 \mathrm{mM}$-tricine (pH 7.9) and $5 \mathrm{mM}-\mathrm{MgCl}_{2}$. The purified organelles were shocked using $25 \mathrm{mM}$-Hepes and $10 \mathrm{mM}$-EDTA (pH 7.5), (shock-buffer). The released membranes were purified by flotation in a discontinuous sucrose gradient $(19,34)$, washed in shock-buffer and resuspended in medium con- taining $0.1 \mathrm{M}-\mathrm{Na}_{2} \mathrm{CO}_{3}$ and $0.1 \mathrm{M}-\mathrm{DTT} \mathrm{pH}$ 9.4. Chlorophyll was determined spectrophotometrically in $80 \%$ acetone extracts according to ARNON (3), and protein concentration according to LowRY et al. (22). Thylakoids not used immediately were frozen in small aliquots at -20 ${ }^{\circ} \mathrm{C}$.

\subsection{Salt washing of barley thylakoids}

Thylakoids from wild-type and mutant $t i$ grina- $o^{34}$ were resuspended in $0.1 \mathrm{M}-\mathrm{Na}_{2} \mathrm{CO}_{3}$ plus $0.1 \mathrm{M}$-DTT pH 9.4 as described in section 2.3. The amount of thylakoids corresponding to $375 \mu \mathrm{g}$ of chlorophyll were washed with $250 \mu \mathrm{l}$ PBS pH 7.2 as described in (15). The membranes were centrifuged $15 \mathrm{~min}$ at $145,000 \times \mathrm{g}$. The final supernatant, PBS-wash, was subjected to SDS-PAGE (sodium dodecyl sulphate polyacrylamide-gel electrophoresis).

\subsection{SDS-PAGE and electrophoretic blotting}

Thylakoid polypeptides were separated in an $11-15 \%$ gradient gel as described by CHUA and BENNOUN (7). The gels were stained with Coomassie blue R-250. Electrophoretic blotting of the polypeptides onto nitrocellulose filters was performed as described earlier $(16,39)$.

\subsection{Immunization of mice with photosystem II vesicles \\ A female BALB/c mouse (Bomholtgaard Ry,} Denmark) was injected intraperitoneally eight times with PS II vesicles. The immunization schedule was as follows: Initially the mouse was given PS II vesicles containing $230 \mu \mathrm{g}$ chlorophyll in $100 \mu \mathrm{l} \mathrm{FCA.} \mathrm{Three} \mathrm{weeks} \mathrm{later} \mathrm{a} \mathrm{second}$ injection with vesicles containing $230 \mu \mathrm{g}$ chlorophyll in $100 \mu 1 \mathrm{FiCA}$ was made, and the same antigen mixture was injected after a further three weeks. Thereafter injections were given weekly. The fourth, fifth and sixth injections contained vesicles with $45 \mu \mathrm{g}$ chlorophyll and $80 \mu \mathrm{l}$ PBS plus $100 \mu \mathrm{l} \mathrm{FiCA}$. The last two times the mouse was given material corresponding to $68 \mu \mathrm{g}$ chlorophyll and $70 \mu \mathrm{l}$ PBS plus $100 \mu \mathrm{l}$ FiCA. The mouse was tailbled after the last boost, and the blood was used in an immune-blot assay. The 
antibody producing mouse was sacrified three days after the eighth injection.

\subsection{Preparation of monoclonal antibodies}

Spleen cells $\left(1.5 \times 10^{8}\right)$ from the immunized mouse were fused with $1.8 \times 10^{8}$ myeloma cells (Sp 2/0-Ag 14) (36) essentially as described by FAzeKAS DE ST. Groth and ScheideGger (10). The fused cells were distributed in ten microtest-plates (Teknunc, Inter Med, Roskilde, Denmark), Each well was previously supplied with $3 \times 10^{3}$ peritoneal mouse macrophages in $200 \mu \mathrm{l}$ HAT-media. The cells were cultured in a $37{ }^{\circ} \mathrm{C}$ humidified incubator supplied with $5 \% \mathrm{CO}_{2}$. One week after the fusion the cells were inspected and $50 \mu \mathrm{lHAT}$ medium was replaced by $37^{\circ} \mathrm{C}$ fresh medium and thereafter 50-100 $\mu$ l HAT medium was renewed every second day. Supernatants of growing hybrids were tested for specific antibody production by an ELISA (enzyme linked immunosorbent assay) using thylakoid polypeptides as antigens. Positive clones were transferred to 24 well multidishes (Teknunc), and when the cells showed confluent growth they were tested for specific antibody production by an immune-blot assay employing either thylakoids or photosystem II vesicles as antigens. About one month after the fusion, the culture media was changed to complete DMEM. Positive clones were cioned by limited dilution (35). The resulting hybridoma clones were grown at $37{ }^{\circ} \mathrm{C}$ in culture bottles (Teknunc). Culture media containing $90 \%$ of the cells was removed every second day and replaced by fresh complete DMEM at $37^{\circ} \mathrm{C}$. This harvest was centrifuged $5 \mathrm{~min}$ at $200 \times \mathrm{g}$ and the antibody containing supernatant was used directly in assays or stored at $-20{ }^{\circ} \mathrm{C}$ for later purification. The hybridoma cells were resuspended in 10\% DMSO in complete DMEM at a concentration of $10^{7}$ cells $/ \mathrm{ml}$ and placed at -70 ${ }^{\circ} \mathrm{C}$ overnight before they were stored in liquid nitrogen (10).

\subsection{Screening assays}

\subsubsection{ELISA}

ELISA were performed in a 96 well microtest plate (Teknunc) at room temperature. The pro-

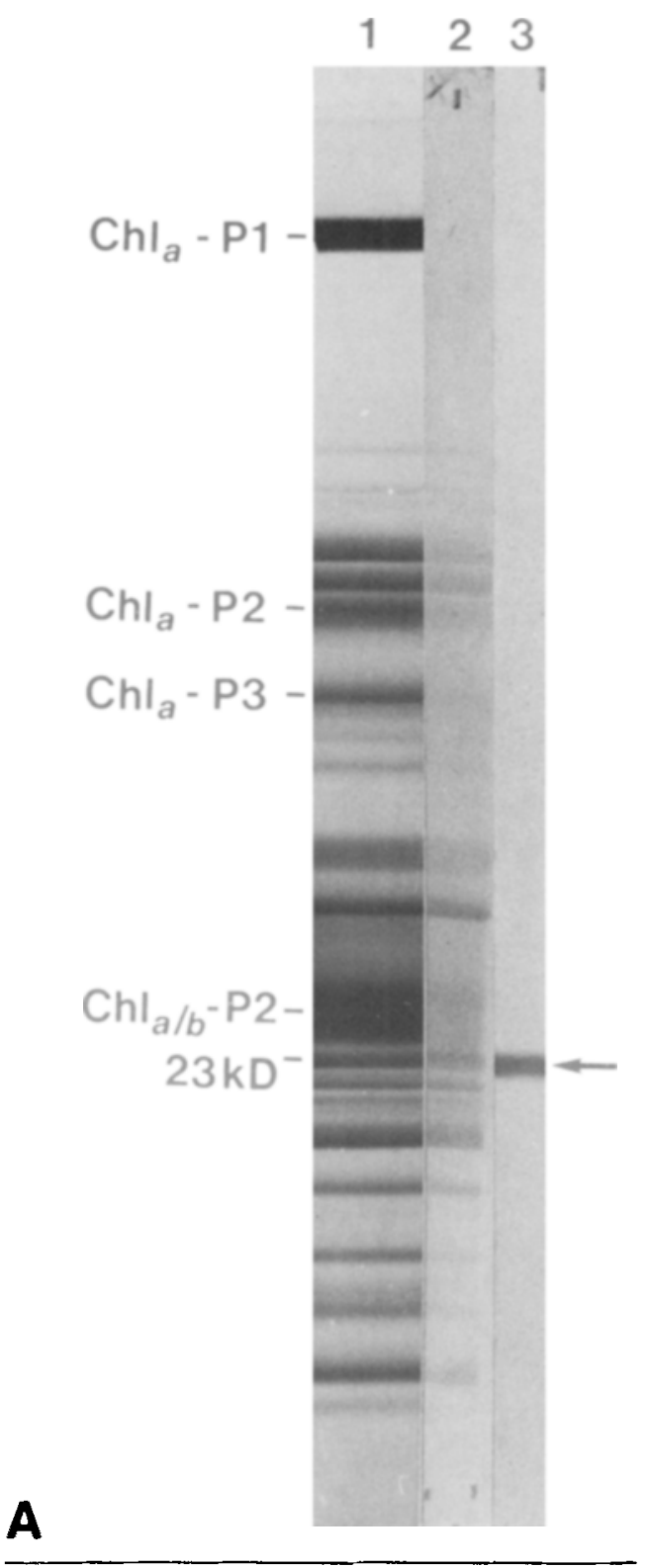

tocol included: a) Adsorption of the antigen to the well. To each well was added $50 \mu \mathrm{l}$ thylakoid membranes at a concentration of $10 \mu \mathrm{g} / \mathrm{ml}$ in PBS which were incubated for two hours. b) Blocking with 3\% BSA in PBS to eliminate nonspecific adsorption to the wells. c) Incubation for two hours with $50 \mu$ l hybridoma supernatant. d) Washing five times with PBS. e) Incubation for one to two hours with $50 \mu \mathrm{l}$ peroxidase conjugated rabbit anti-mouse im- 


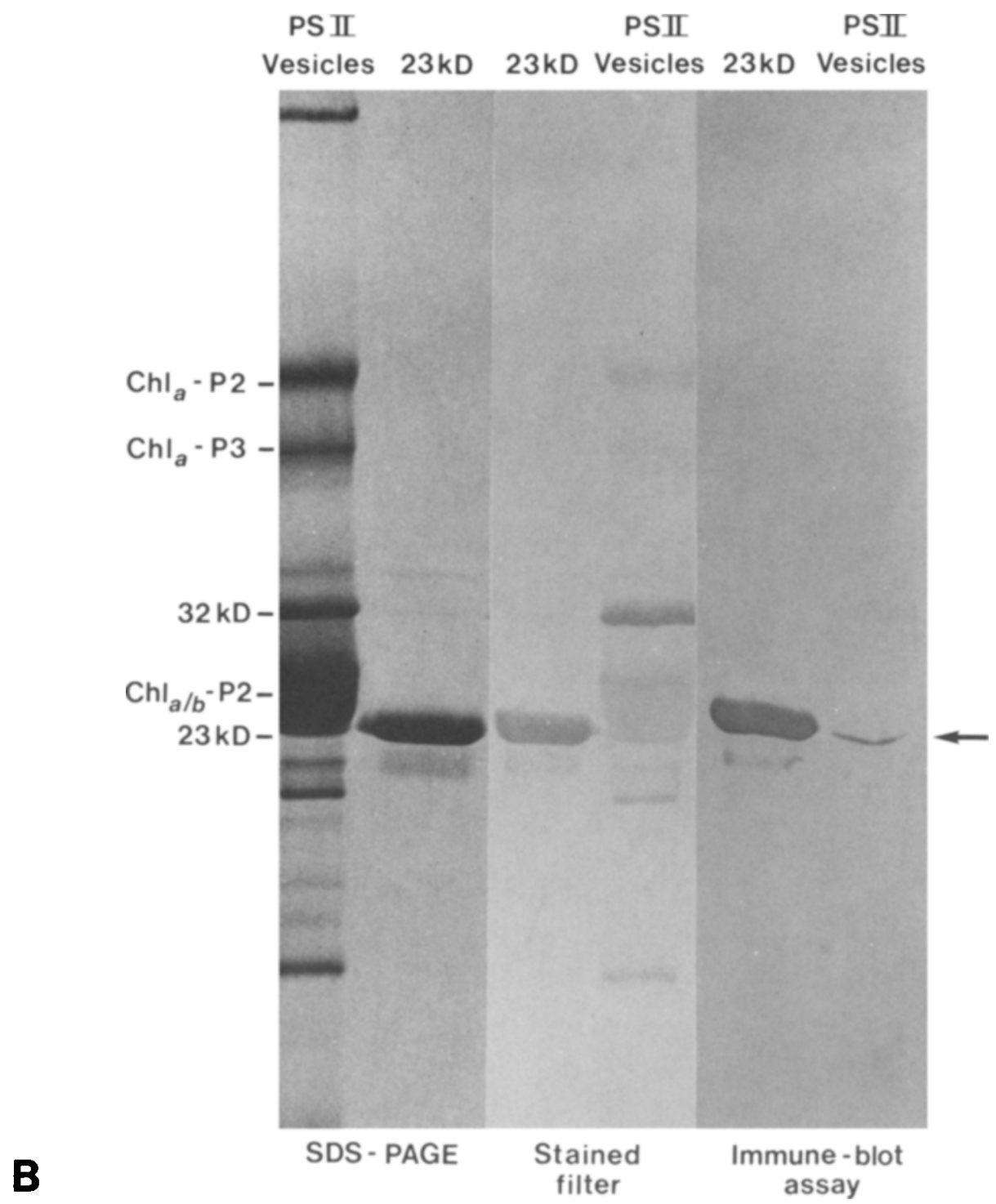

Figure 1. Immune-blot assay for the identification of the $23 \mathrm{kD}$ polypeptide using a monoclonal antibody. The polypeptides were separated by SDS-PAGE and were then electrophoretically transferred to nitrocellulose filters. These were employed in immune-blot assays using a monoclonal antibody to the $23 \mathrm{kD}$ polypeptide. As secondary antibody a rabbit anti-mouse coupled to peroxidase was employed and colour was developed with 3-amino-9-ethylcarbazole and $\mathrm{H}_{2} \mathrm{O}_{2}$. Reacting polypeptides are marked with arrows. 1A: Thylakoid polypeptides (20 $\mathrm{g}$ chlorophyll applied). Lane 1: SDS-PAGE, lane 2: filter stained with Amido-black, lane 3: filter employed in an immune-blot assay. 1B: PS II vesicles ( $20 \mu \mathrm{g}$ chlorophyll applied) and purified 23 $\mathrm{kD}$ polypeptide.

munoglobulin at a concentration of $2 \mu \mathrm{l} / \mathrm{ml} 10 \%$ NBC in PBS $(v / v)$. f) Washing five times with PBS. g) Colour development with hydrogen peroxide and 3-amino-9-ethylcarbazole (11).

\subsubsection{Immune-blot assay}

Strips of nitrocellulose filters containing immobilized electrophoretically separated polypeptides $(16,39)$ were incubated in $10 \% \mathrm{NBC}$ 


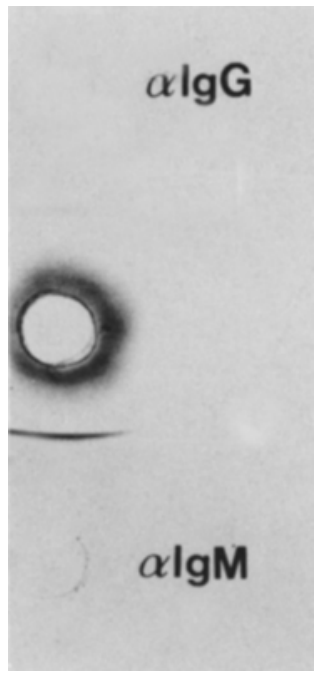

Figure 2. Double immunodiffusion test according to Ouchterlony reveals that the hybridoma line to the $23 \mathrm{kD}$ polypeptide is an IgM.

Hybridoma supernatant $(40 \mu \mathrm{l})$ was added to the centre well, and $(15 \mu \mathrm{l})$ goat anti-mouse IgG and IgM were added to peripheral wells.

$(v / v)$ in PBS to prevent unspecific binding to the filters. The strips were then rinsed in PBS and incubated for two hours with either hybridoma supernatant or purified monoclonal antibodies $(45 \mu \mathrm{g} / \mathrm{ml})$ in $10 \% \mathrm{NBC}$ in PBS at $37^{\circ} \mathrm{C}$ with occasional agitation. After washing five times during $30 \mathrm{~min}$ with $1 \% \mathrm{BSA}(\mathrm{w} / \mathrm{v}$ ) in PBS, the strips were incubated in $10 \%$ NBC containing peroxidase conjugated rabbit anti-mouse immunoglobulin $(2 \mu \mathrm{l} / \mathrm{ml} \mathrm{NBC})$. An additional five washes in PBS were made, and then the strips were stained with 3-amino-9-ethylcarbazole as described in (11).

\subsection{Determination of the immunoglobulin class of the monoclonal antibodies \\ 2.9.1. Double immunodiffusion in gels}

The immunoglobulin class of the antibody was initially determined by an Ouchterlony double immunodiffusion $(32,33,35)$ performed at room temperature in $1 \%(\mathrm{w} / \mathrm{v})$ agarose containing $50 \mathrm{~mm}$-Tris- $\mathrm{HCl}$ (pH 8.6) plus $0.1 \mathrm{M}$ $\mathrm{NaCl}$. Hybridoma supernatant was added to the centre well, and goat anti-mouse IgG and IgM (Meloy), were added to peripheral wells.

\subsubsection{Biosynthetic labelling of antibodies}

Hybridoma cells $\left(1.5 \times 10^{6}\right)$ were cultured overnight in $1 \mathrm{ml}$ culture media supplied with 50 $\mu \mathrm{Ci}{ }^{35} \mathrm{~S}$-methionine instead of unlabelled methionine (35). The next day the cells were removed by centrifugation, and the antibody in the supernatant was reduced with mercaptoethanol and subjected to SDS-PAGE. After electrophoresis the gel was immersed in 50\% metha$\mathrm{nol}(\mathrm{v} / \mathrm{v})$ for at least one hour and prepared for fluorography with $1 \mathrm{M}$-sodium salicylate in glycerol: methanol: water $(3: 48.5: 48.5, \mathrm{v} / \mathrm{v} / \mathrm{v})$ for $15-20 \mathrm{~min}$ (6), dried and exposed overnight to RP 1 Royal X-Omat film at $-70^{\circ} \mathrm{C}$. The immunoglobulin class was assigned after determining the molecular weight of the heavy chain (14).

\subsection{Purification of the monoclonal antibodies}

Monoclonal antibodies of the IgM class were purified by $50 \%(\mathrm{w} / \mathrm{v})\left(\mathrm{NH}_{4}\right)_{2} \mathrm{SO}_{4}$ precipitation overnight at $4{ }^{\circ} \mathrm{C}(35)$. After centrifugation the resultant pellet was dissolved in elution buffer (0.1 M-Tris- $\mathrm{HCl}$ at $\mathrm{pH} 7.8$ plus $0.5 \mathrm{M}-\mathrm{NaCl}$ ), and dialysed overnight in the same buffer which was changed twice. The dialysed sample was centrifuged to remove the denatured proteins before the sample was chromatographed on a Sephacryl S-300 column equilibrated in elution buffer. The eluted fractions were tested for specific antibody activity in an immune-blot assay (section 2.8). Positive fractions were pooled and dialysed against PBS (pH 7.2) at $4{ }^{\circ} \mathrm{C}$. Protein concentration was determined according to LOWRY et al. (22).

\section{RESULTS}

\subsection{Characterization of the monoclonal} antibody to the $23 \mathrm{kD}$ polypeptide

Initial experiments in which $10^{8}$ spleen cells obtained from a mouse injected three times with the antigen were fused with $6 \times 10^{7}$ myeloma cells gave a fusion frequency of $50 \%$. By changing the immunization schedule from three 


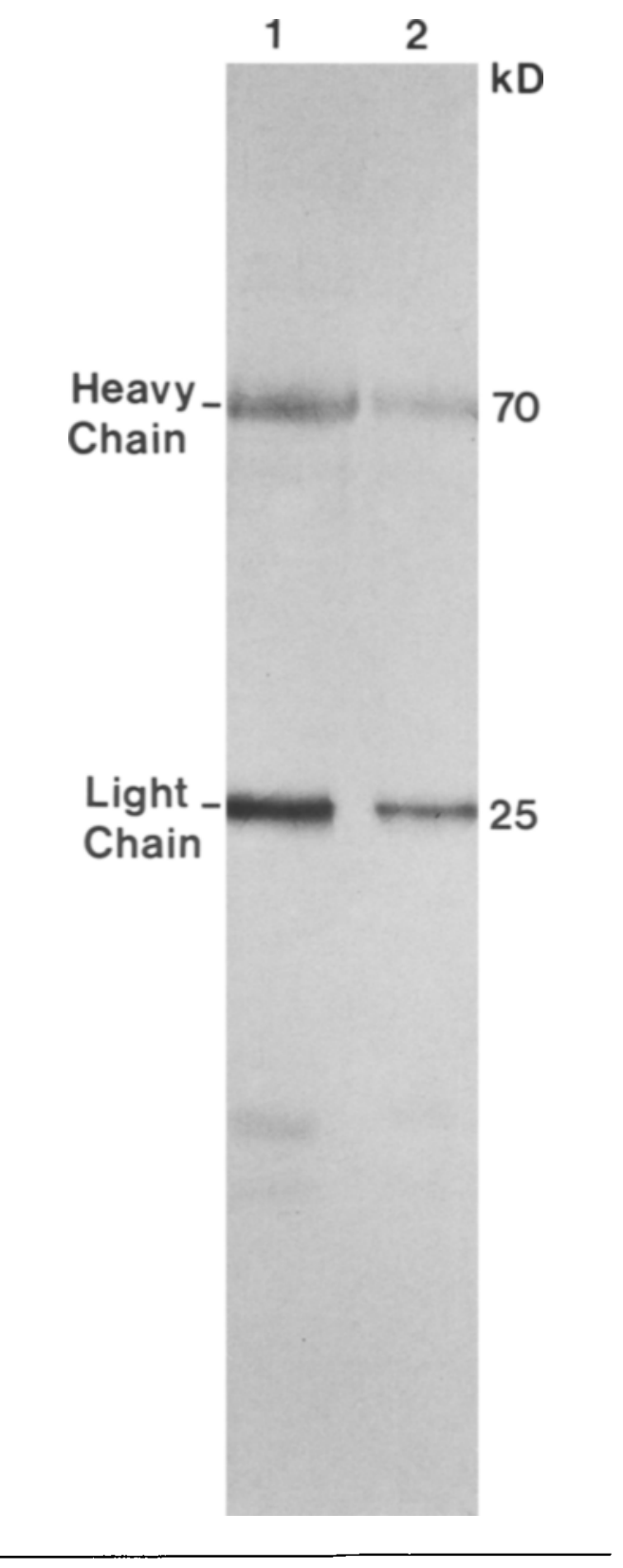

to eight injections and raising the number of spleen cells from $10^{8}$ to $1.5 \times 10^{8}$ and the number of myeloma cells from $6 \times 10^{7}$ to $1.8 \times 10^{8}$ cells, the fusion frequency was raised to between 80 and $90 \%(15)$. The hybridoma lines obtained were scored for the ability to secrete antibodies to polypeptides present in thylakoid mem-
Figure 3. Determination of the immunoglobulin class by biosynthetic labelling of antibodies.

Hybridoma cells were cultured overnight in a medium containing ${ }^{35} \mathrm{~S}$-methionine. The supernatant containing the secreted antibodies was subjected to SDS-PAGE, processed for fluorography according to Chamberlain (6) and the dried gel was exposed to RP 1 Royal X-Omat film overnight at $-70^{\circ} \mathrm{C}$. Lane 1: $40 \mu$ l hybridoma supernatant applied. Lane 2: 25 $\mu \mathrm{l}$ supernatant applied to the gel. The immunoglobulin class of the antibody was determined according to the molecular weight of the heavy chain (14). As molecular weight standards hybridomas secreting defined antibodies of the IgM and IgG classes were used.

branes. Initially, the hybridoma clones showing confluent growth were subjected to ELISA using thylakoids as antigens. The supernatants from the positive clones were subsequently tested by an immune-blot assay employing electrophoretically separated polypeptides from thylakoids and photosystem II vesicles as antigens. Approximately $10 \%$ of the hybridoma lines tested gave positive results. Among these, one of the clones reacted with a 23,000 molecular weight protein present in both the thylakoids and the PS II vesicles, as well as with the purified $23 \mathrm{kD}$ polypeptide (Figures $1 \mathrm{~A}$ and $\mathrm{B}$, respectively). In the immune-blot assay of Figure $1 \mathrm{~A}$, the antibody has reacted only with the polypeptide of 23,000 molecular weight. Figure 1B lane 5 shows that the antibody also reacts with a polypeptide of $20 \mathrm{kD}$, which is sometimes present. The smaller polypeptide is thought to be a transformation product of the $23 \mathrm{kD}$ polypeptide $(15,27)$. Increasing the antibody concentration six-fold gave an additional reaction with the $32 \mathrm{kD}$ polypeptide (not shown). The immunoglobulin class of this hybridoma line was shown to be IgM by double immunodiffusion according to OUCHTERLONY (32) (Figure 2) and biosynthetic labelling of the antibodies (Figure 3). After cloning by limited dilution, the identified hybridoma line was cultured in large scale and the secreted monoclonal antibodies were purified from the culture media. 
L.S. Hønkerg: Probing barley mutants with a monoclonal antibody

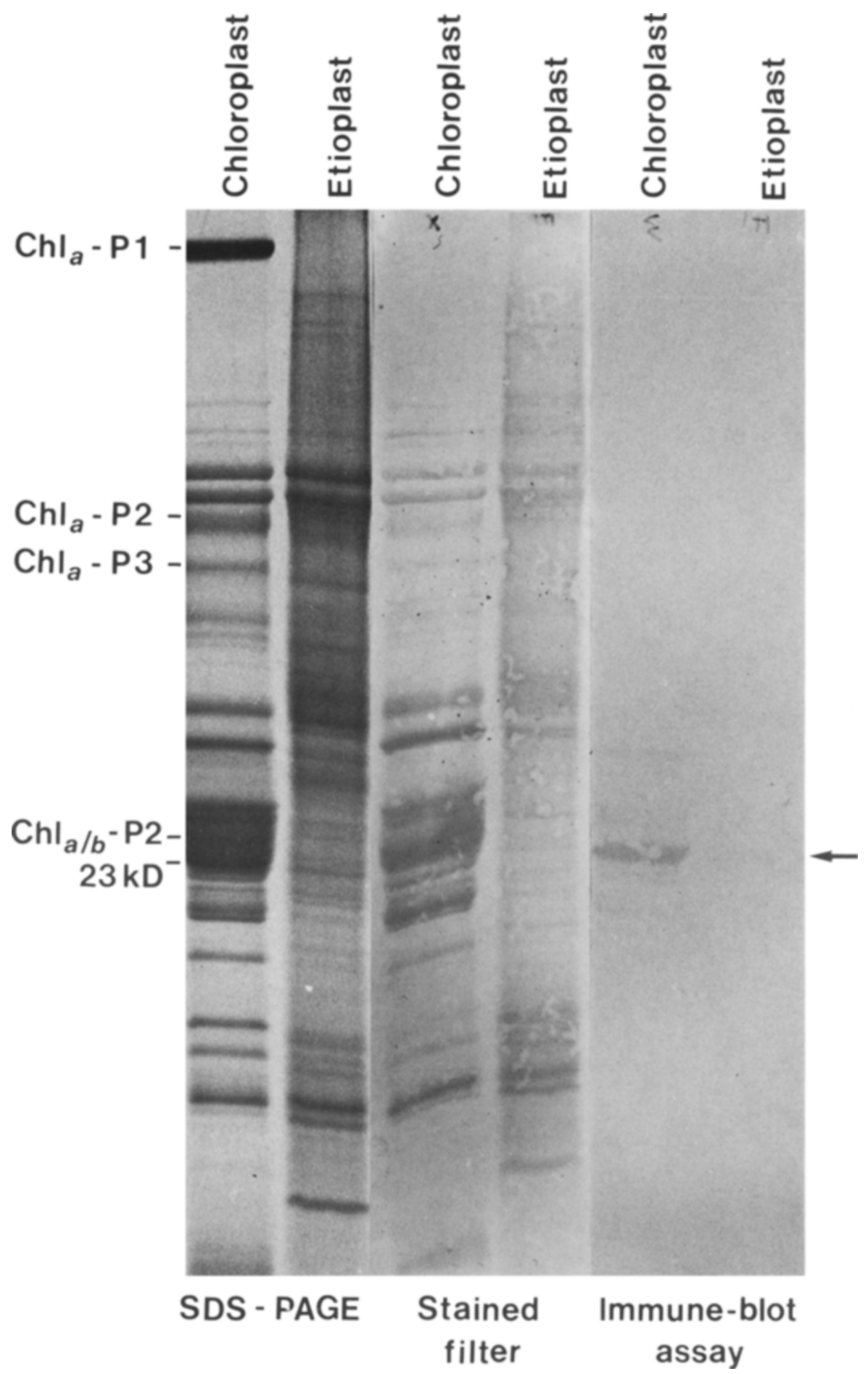

Figure 4. Immune-blot assay to test for the presence of the $23 \mathrm{kD}$ polypeptide in internal chloroplast and etioplast membranes using the monoclonal antibody.

$125 \mu \mathrm{g}$ of protein from isolated internal chloroplast and etioplast membranes were employed as antigens in the assay. 
L.S. HøNBERG: Probing barley mutants with a monoclonal antibody

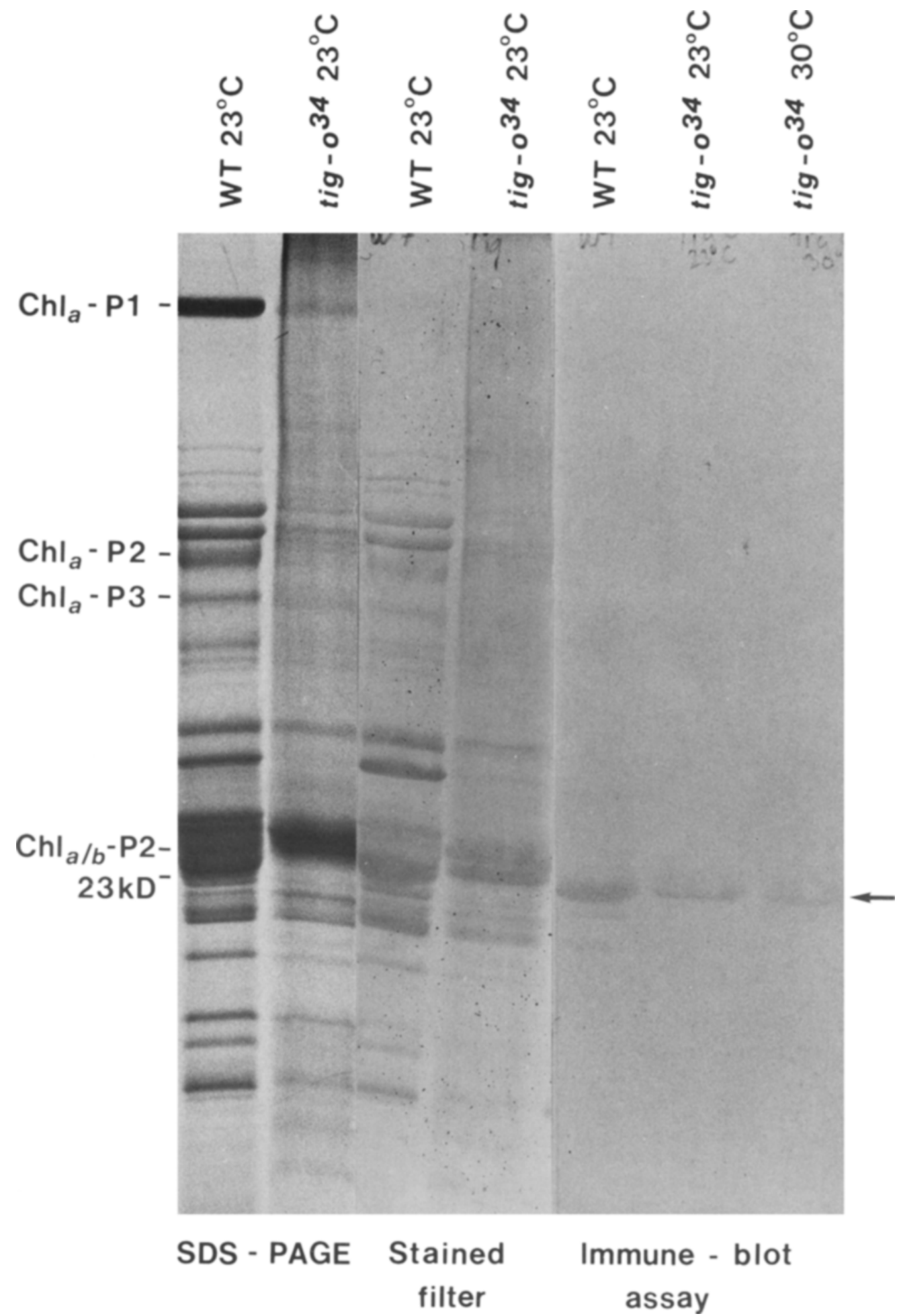

Figure 5. Probing thylakoids isolated from wild-type and mutant tigrina- $0^{34}$ grown at $23{ }^{\circ} \mathrm{C}$ and $30{ }^{\circ} \mathrm{C}$ with the monoclonal antibody to the $23 \mathrm{kD}$ polypeptide in an immune-blot assay.

Thylakoids $\left(20 \mu \mathrm{g}\right.$ chlorophyll) from wild-type (WT) grown at $23{ }^{\circ} \mathrm{C}$ and mutant grown at $23{ }^{\circ} \mathrm{C}$ and 30 ${ }^{\circ} \mathrm{C}$ were applied to the gel. 
L.S. HøNBERg: Probing barley mutants with a monoclonal antibody

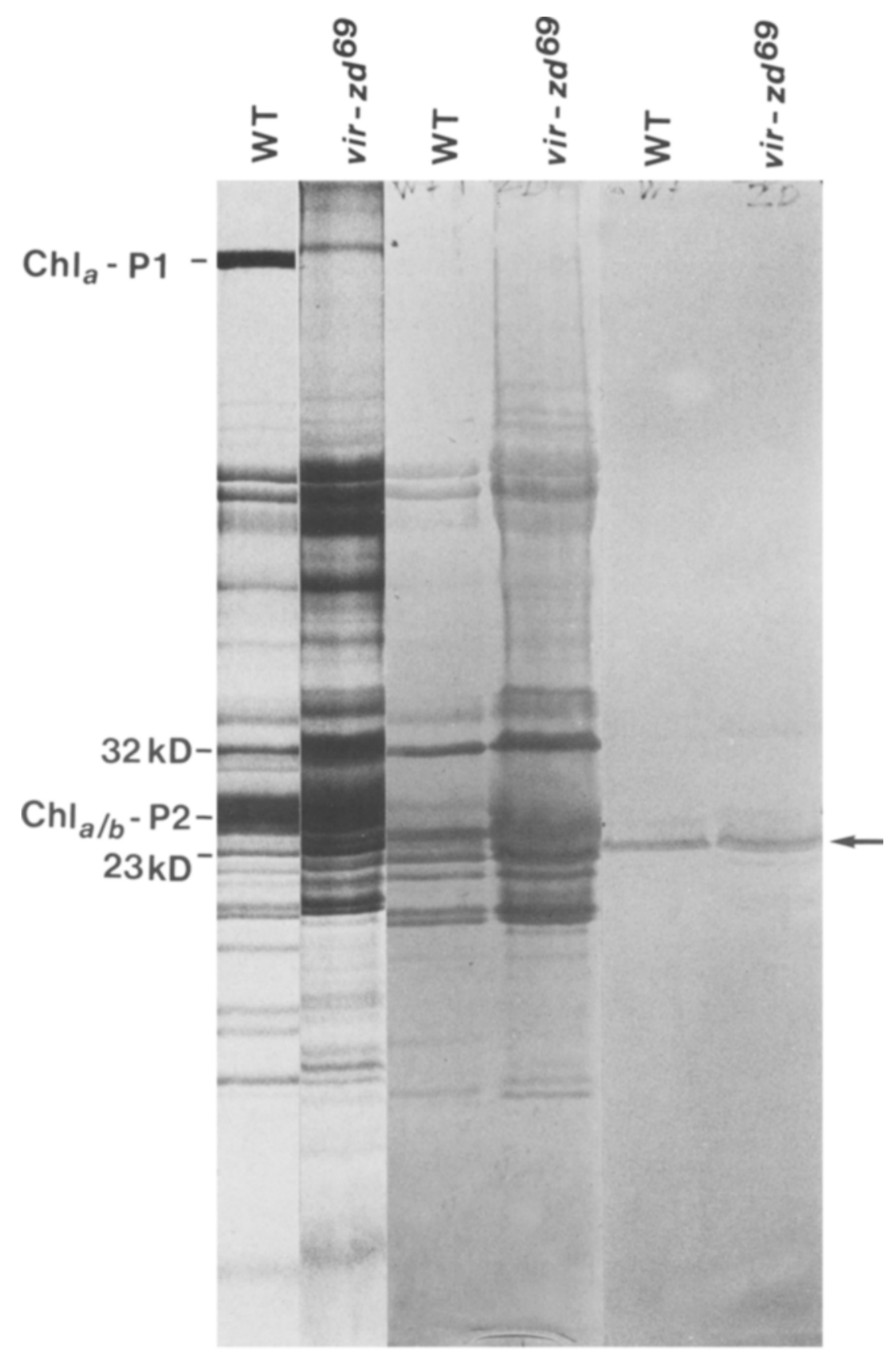

\section{SDS-PAGE Stained Immune-blot filter assay}

Figure 6. Immune-blot assay to test for the presence of the $23 \mathrm{kD}$ polypeptide in mutant viridis- $z d^{69}$ thylakoids. Thylakoids (20 $\mu \mathrm{g}$ chlorophyll) from wild-type (WT) and viridis-zd ${ }^{69}$ were applied to the gel. 


\subsection{Probing polypeptides from internal etioplast membranes with the antibody to the $23 \mathrm{kD}$ polypeptide.}

Figures $\mathrm{A}$ and $\mathrm{B}$ illustrate that the monoclonal antibody recognized a $23 \mathrm{kD}$ polypeptide present in polypeptide preparations of thylakoid membranes and PS II vesicles isolated from light grown seedlings. An analogous experiment was carried out to determine if the $23 \mathrm{kD}$ polypeptide is present in internal etioplast membranes. Equal amounts $(125 \mu \mathrm{g})$ of protein of a chloroplast and an etioplast preparation were applied to an SDS gel, and after electrophoresis the polypeptides were transferred to a nitrocellulose filter. The $23 \mathrm{kD}$ polypeptide was not detectable in the internal etioplast membranes by this immune-blot assay (Figure 4). A three-fold increase in the amount of internal etioplast membranes did not result in any detectable band due to reaction with the antibody, whereas it was possible to lower the amount of chloroplast proteins from $125 \mu \mathrm{g}$ to $25 \mu \mathrm{g}$ and still detect the $23 \mathrm{kD}$ polypeptide. Thus the amount of this polypeptide in etioplasts is at most one-twentieth of that found in chloroplast membranes.

\subsection{Probing polypeptides from the mutant tigrina-o ${ }^{36}$ and three viridis mutants with the antibody to the $23 \mathrm{kD}$ polypeptide}

\subsubsection{Immune-blot assays}

Thylakoid polypeptides isolated from the cold-sensitive mutant tigrina- $o^{34}$ grown at $23^{\circ} \mathrm{C}$ or $30{ }^{\circ} \mathrm{C}$ and separated by SDS-PAGE were transferred to nitrocellulose filters. These were probed with the monoclonal antibody to the $23 \mathrm{kD}$ polypeptide. Figure 5, lanes 2 and 4 indicates that a $23 \mathrm{kD}$ polypeptide was present in the mutant thylakoids when the plants were grown at $23{ }^{\circ} \mathrm{C}$. This was confirmed by the immune-blot assay, which also demonstrated that the $23 \mathrm{kD}$ polypeptide was present in thylakoids from mutant plants grown at $30^{\circ} \mathrm{C}$ (Figure 5, lanes 6 and 7). Since equal amounts of chlorophyll $(20 \mu \mathrm{g})$ were applied to the gel from wild-type and the mutant grown at both temperatures, it was concluded that the same amount of the polypeptide is present in tigrina$o^{34}$ plants grown at the two temperatures. The amount of the polypeptide, however, was clearly reduced in the mutant compared to the wildtype (Figure 5, lanes 5 and 6).

Additionally, thylakoid polypeptides isolated from the photosystem II mutants viridis- $z d^{69}$, viridis $-m^{29}$ and viridis- 115 were probed with the antibody to the $23 \mathrm{kD}$ polypeptide in an immune-blot assay. The amount of chlorophyll applied to the gel was again the same in the mutants as in the wild-type $(20 \mu \mathrm{g})$. Figures 6 and 7 reveal that the $23 \mathrm{kD}$ polypeptide was present in equal amounts in the three mutants viridis- $z d^{69}$, viridis- $m^{29}$, viridis- 115 and the wildtype.

\subsubsection{Salt washing of thylakoids isolated from wild-type and mutant tigrina-o ${ }^{34}$ barley}

Thylakoids isolated from seedlings of the wild-type and the nuclear gene mutant tigrina$o^{34}$, grown at $30^{\circ} \mathrm{C}$ were resuspended in $\mathrm{Na}_{2} \mathrm{CO}_{3-}$ DTT as described in section 2.3. The mutant and the wild-type thylakoids containing $375 \mu \mathrm{g}$ of chlorophyll were washed with PBS at pH 7.2. After centrifugation the supernatant was subjected to SDS-PAGE. The electrophoretogram of the Coomassie-blue stained gel showed that salt-washing of barley wild-type thylakoids releases at least eight bands including the $\alpha$ and $\beta$ subunits of $C F_{1}$, plus major bands of $M_{r}$ $32,000,23,000$ and 10,000 (Figure 8). No polypeptide bands were visible after Coomassie-blue staining of the supernatant of the salt-washed thylakoids from the mutant tigrina- $o^{34}$.

\section{DISCUSSION}

The mouse sacrificed in the fusion to obtain the monoclonal antibody to the $23 \mathrm{kD}$ polypeptide had been immunized eight times with PS II vesicles. With this high stimulation it was expected that the resulting antibody response would yield antibodies of the IgG immunoglobulin class. The monoclonal antibody reacting specifically with the $23 \mathrm{kD}$ polypeptide, however, was determined to be of the IgM class. This could be because the amount of protein injected was low, or that the $23 \mathrm{kD}$ polypeptide does not stimulate the immunesystem of the 
L.S. Høngerg: Probing barley mutants with a monoclonal antibody

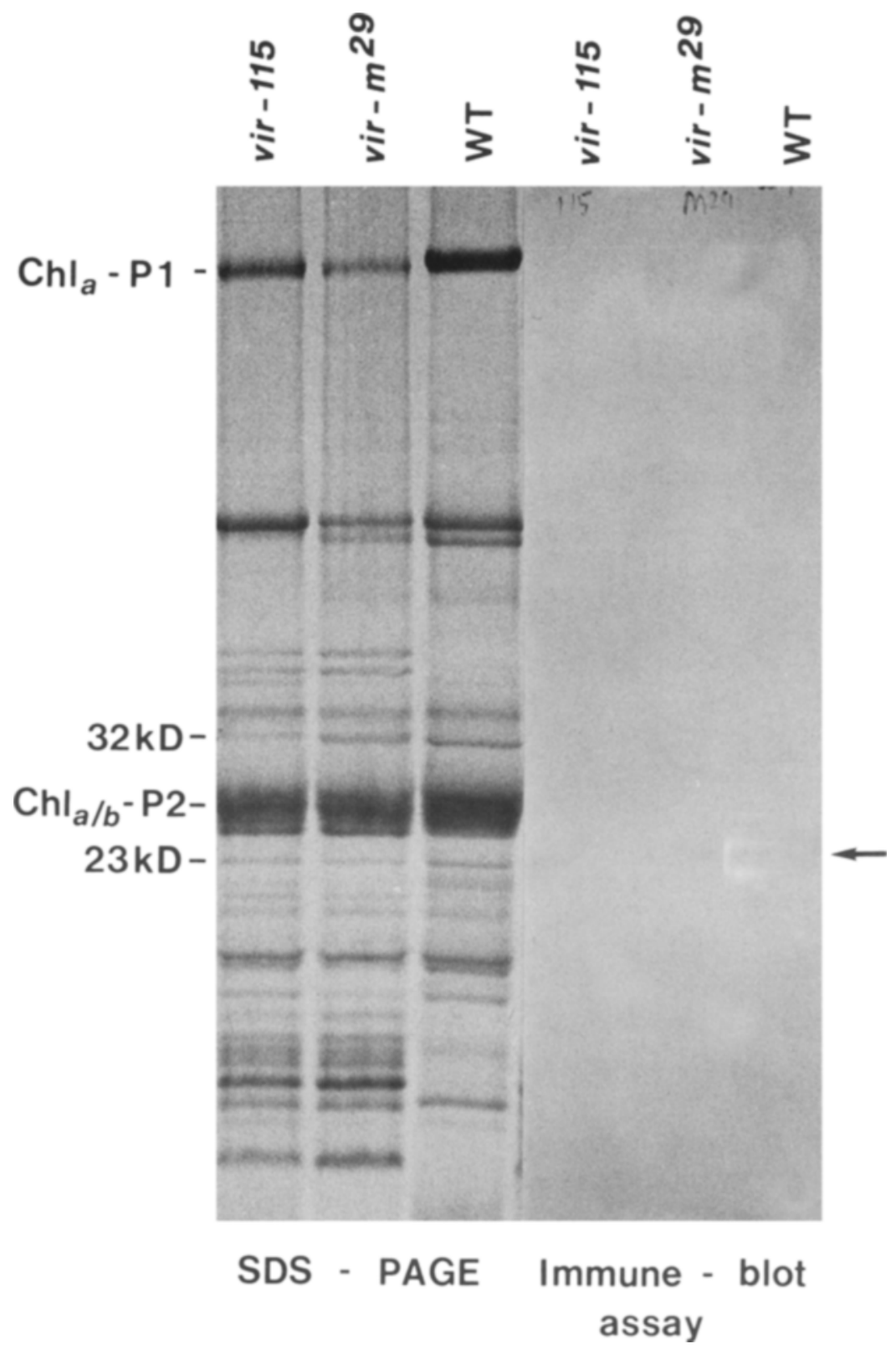

Figure 7. Probing thylakoids isolated from wild-type and the mutants viridis- $m^{29}$ and viridis- 115 with the monoclonal antibody to the $23 \mathrm{kD}$ polypeptide in an immune-blot assay.

Thylakoids ( $20 \mu \mathrm{g}$ chlorophyll) from the wild-type (WT) and the two mutants were applied to the gel.

mouse to produce antibodies of the immunglobulin $\mathrm{G}(\mathrm{IgG})$ class.

The monoclonal antibody reacting with the $23 \mathrm{kD}$ polypeptide also weakly reacted with a polypeptide of apparent molecular weight
32,000 (15). Since the employed hybridoma line had been cloned by limited dilution (35), this cannot be due to a mixture of antibodies. Each monoclonal antibody has a unique binding site, so the cross reaction observed must be due to 


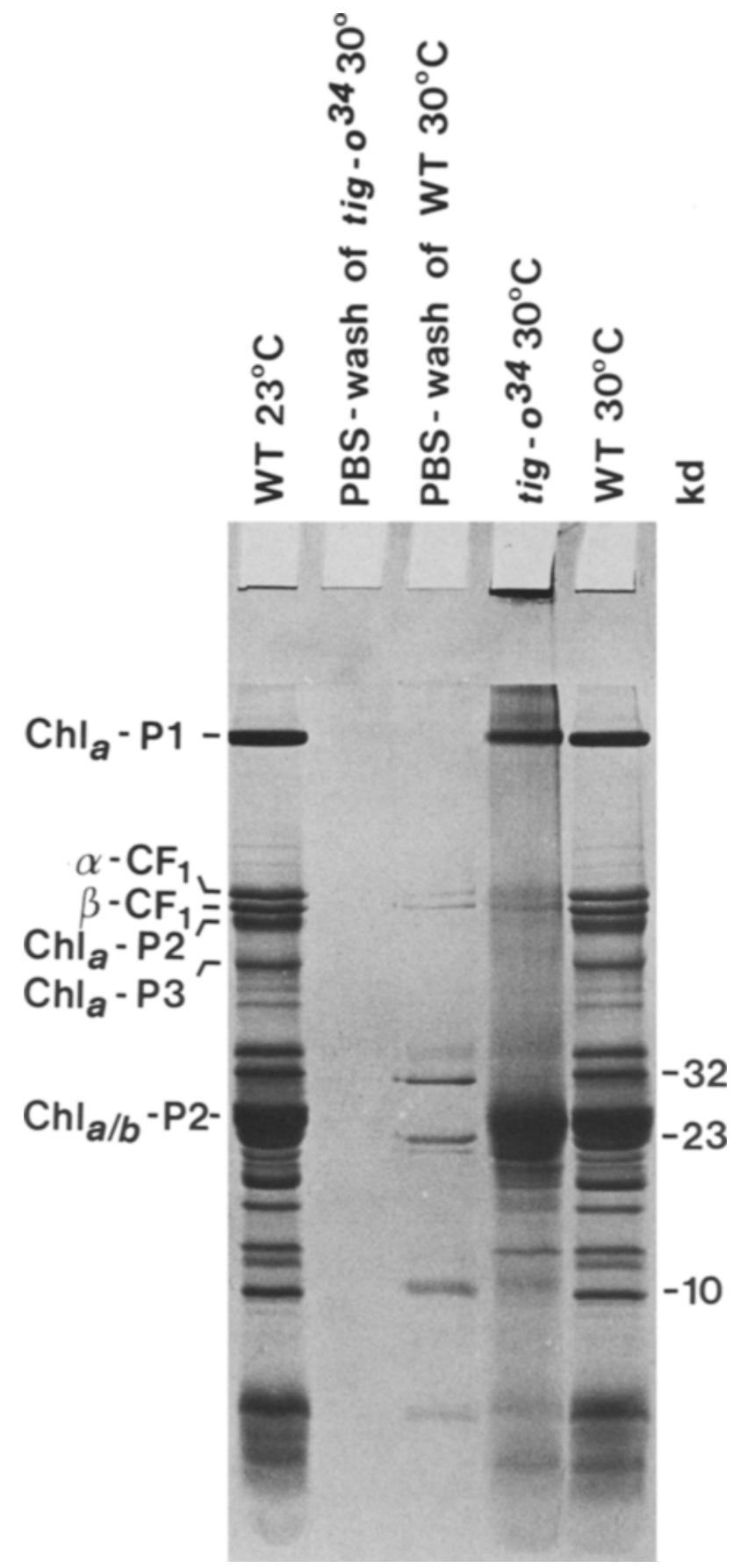

Figure 8. Salt-washing of thylakoids isolated from wild-type and mutant tigrina-o $o^{34}$ grown at $30^{\circ} \mathrm{C}$.

Thylakoids from the wild-type and the mutant corresponding to $375 \mu \mathrm{g}$ chlorophyll were washed with 250 $\mu \mathrm{I}$ PBS pH 7.2 (15). The membranes were centrifuged 15 min at $145,000 \times \mathrm{g}$. The final supernatants, PBS-washes, were subjected to SDS-PAGE in parallel with thylakoids ( $20 \mu \mathrm{g}$ chlorophyll) from wild-type and mutant germinated at $30^{\circ} \mathrm{C}$ and the wild-type at $23{ }^{\circ} \mathrm{C}$. 
a similar antigenic site in the $23 \mathrm{kD}$ and the $32 \mathrm{kD}$ polypeptides $(15,17,26)$.

Once an antibody producing hybridoma line has been established, unlimited amounts of the antibody directed against a single antigenic determinant is available. These antibodies can be employed in immune-blot assays to screen for the presence of the antigen in different polypeptide preparations e.g., isolated thylakoid preparations from mutants. The immune-blot assay in Figure 4 shows that the $23 \mathrm{kD}$ polypeptide is present in barley chloroplasts, but is not detectable in internal etioplast membranes. Increasing amounts of etioplast membranes did not reveal the presence of the $23 \mathrm{kD}$ polypeptide. This strongly implies that the synthesis of the $23 \mathrm{kD}$ polypeptide and its incorporation into the thylakoids takes place during the light dependent development of the chloroplast.

The $23 \mathrm{kD}$ polypeptide can be released together with two or three other polypeptides from inside-out PS II vesicles by high salt treatment resulting in an inhibition of oxygen evolution $(1,2,20,27)$. Photosynthetic oxygen evolution can be reconstituted by rebinding the $23 \mathrm{kD}$ polypeptide to the salt washed PS II vesicles (1, 2 , 27). The precise function of the $23 \mathrm{kD}$ polypeptide is not clear, but it might have a structural or a regulatory function in binding chloride ions (2). Since the $23 \mathrm{kD}$ polypeptide is a component of the oxygen evolving complex, it was of interest to study mutants defective in photosystem II activity. Viridis- $z d^{69}$, viridis- $m^{29}$ and viridis- 115 have greatly reduced or no photosystem II activity $(24,37,43)$. The presence of the $23 \mathrm{kD}$ polypeptide could be demonstrated in all three viridis mutants by an immune-blot assay.'Thus the photosynthetic defects in these mutants cannot be due to a lack of this $23 \mathrm{kD}$ polypeptide, which has been synthesized and transported through the thylakoid membranes (Figures 6 and 7). Freeze fracture electron microscopy of the grana membranes of the mutants has shown that the number of particles on the endoplasmic fracture face (EFs) is greatly reduced compared to wild-type, whereas the mutant membranes have a normal protoplasmic fracture face (PFs) $(37,42,43)$. The reduction in the number of EFs particles has been shown to be proportional to the reduction in PS II activity in mutants of barley as well as Chlamydomonas $(31,43)$. The ESs tetrameric particles, which are the surface projections of EFs particles, have been suggested as the likely site of the oxygen evolving complex. Assuming that the EFs particle is the site of the photosystem II reaction centre, the oxygen evolving complex of which the $23 \mathrm{kD}$ polypeptide is a component might exist as a separate entity. That is, the oxygen evolving complex would be structurally distinct from the photosystem II reaction centre although functionally associated with it. Alternatively, it could be that the $23 \mathrm{kD}$ polypeptide might be a component of the reaction centre of photosystem II perhaps located in the tetrameric ESs particles. In the absence of a nuclearcoded polypeptide normally associated with the reaction centre complex in these mutants, however, the components of the EFs particles are not assembled and are presumably destroyed by a protease located in the thylakoids. The 23 $\mathrm{kD}$ polypeptide would thus lack its normal binding site in the thylakoid and remain in the lumen of the thylakoids where the polypeptide is not accessible to protease attack.

To determine the site of synthesis of the 23 $\mathrm{kD}$ polypeptide, its presence in the temperature and light sensitive mutant tigrina- $o^{34}(5,17)$ was studied. In white light at $23{ }^{\circ} \mathrm{C}$, the chloroplast ribosomes of this mutant are destroyed, while cytoplasmic ribosomes are retained in normal amounts. The destruction of the chloroplastic ribosomes can be prevented by growing the mutant seedlings at $30^{\circ} \mathrm{C}$. At this permissive temperature, the mutant polypeptide pattern resembles that of the wild-type although normal photosynthetic function is not restored (17). The polypeptide composition of the mutant grown at the restrictive temperature reveals a reduction or complete absence of chlorophyll- $a$ proteins 1,2 and 3 , cytochrome $f$ and the subunits of coupling factor-1 $\left(\mathrm{CF}_{1}\right)(17)$. These proteins, except $\delta$ and $\gamma$ subunit of $\mathrm{CF}_{1}$, have been shown in other species such as spinach $(25,41)$, pea (9) and Chlamydomonas reinhardtii (8) to be synthesized in the chloroplasts $(17,25)$. This investigation has demonstrated that the $23 \mathrm{kD}$ polypeptide is present in the mutant tigrina- $o^{34}$, although the protein is found in decreased amounts compared to wild-type both at the 
restrictive and permissive temperatures. Since tigrina- $o^{34}$ grown at $23{ }^{\circ} \mathrm{C}$ has no chloroplast ribosomes, no $23 \mathrm{kD}$ polypeptide could be present in plants grown at the restrictive temperature if the polypeptide was coded in chloroplast-DNA. Its existence indicates that the polypeptide is coded by a nuclear gene, in agreement with results obtained by WESTHOFF et al. who report that the 34,23 and $16 \mathrm{kD}$ proteins are translated from poly-A RNA (40). The inability to recover these polypeptides with salt-washing from thylakoids of mutant tigrina- $o^{34}$ at the restrictive temperature (figure 8 , lane 2 ) indicates that they are not bound to the membranes in the mutant.

\section{ACKNOWLEDGEMENTS}

I wish to thank Dr. G. HøYER-HANSEN for continuous encouragement, many stimulating discussions and for her critical reading of the manuscript. Thanks are also due to Dr. P. voN WETTSTEIN-KNOWLES and Dr. D. SIMPSON for reviewing the manuscript. Professor B.L. MøLLER and Cand. scient. P.B. HøJ are thanked for providing PS II vesicles and a preparation of isolated $23 \mathrm{kD}$ polypeptide. T. BEKTVED, $\mathrm{N}$. RASMUSSEN and A.-S. STEINHOLTZ are acknowledged for their skilful technical assistance.

\section{REFERENCES}

1. Ákerlund, H.-E., C. JANSSON \& B. ANDERSSON: Reconstitution of photosynthetic water splitting in inside-out thylakoid vesicles and identification of a participating polypeptide. Biochim. Biophys. Acta 681, 1-10 (1982)

2. Andersson, B., C. Critchley, i.J. Ryrie, C. JANSSON, C. LARSSON \& J.M. ANDERSON: Modification of the chloride requirement for photosynthetic $\mathrm{O}_{2}$ evolution. The role of the $23 \mathrm{kDa}$ polypeptide. FEBS Lett. 168, 113-117 (1984)

3. ARnON, D.I.: Copper enzyme in isolated chloroplasts. Polyphenoloxidase in Beta vulgaris. Plant Physiol. 24, 1-14 (1949)

4. BERTHOLD, D.A., G.T. BABOCK \& C.F. YoCUM: A highly resolved, oxygen-evolving photosystem II preparation from spinach thylakoid membranes. EPR and electron transport properties. FEBS Lett. 134, 231-234 (1981)
5. Casadoro, G., G. Høyer-Hansen, C.G. KanNANGARA \& S.P. GoUGH: An analysis of temperature and light sensitivity in tigrina mutants of barley. Carlsberg Res. Commun. 48, 95-129 (1983)

6. Chamberlain, J.P.: Fluorographic detection of radioactivity in polyacrylamide gels with the water-soluble fluor, sodium salicylate. Anal. Biochem. 98, 132-135 (1979)

7. Chua, N.-H.\&.P. BenNoun: Thylakoid membrane polypeptides of Chlamydomonas reinhardtii: Wild type and mutant strains deficient in photosystem II reaction center. Proc. Nat. Acad. Sci. USA 72, 2175-2179 (1975)

8. Chua, N.-H. \& N.W. Gillham: The sites of synthesis of the principal thylakoid membrane polypeptides in Chlamydomonas reinharditi. J. Cell. Biol. 74, 441-452 (1977)

9. Doherty, A. \& J.C. Gray: Synthesis of cytochrome $f$ by isolated pea chloroplasts. Eur. J. Biochem. 98, 87-92 (1979)

10. Fazekas de St. Groth, S. \& D. ScheidegGer: Production of monoclonal antibodies: strategy and tactics. J. Immunol. Meth. 35, 1-21 (1980)

11. Graham, R.C. JR., U. Lundholm \& M.J. KaRNOVSKY: Cytochemical demonstration of peroxidase activity with 3-amino-9-ethylcarbazole. J. Histochem. Cytochem. 13, 150-153 (1965)

12. Henry, L.E.A. \& B.L. Møller: Polypeptide composition of an oxygen evolving photosystem II vesicle from spinach chloroplats. Carlsberg Res. Commun. 46, 227-242 (1981)

13. Hiller, R.G., B.L. Møller \& G. Høyer.Hansen: Characterization of six putative photosystem I mutants in barley. Carlsberg Res. Commun. 45, 315-328 (1980)

14. Hobart, M.J.: Immunoglobulins as proteins. In: The Immune System, a course on the molecular and cellular basis of immunity. M.J. Hobart \& I. McConnell, eds., London, pp 2-15 (1975)

15. HønberG, L.S.: Monoclonal antibodies to $23 \mathrm{kD}$ and $18.3 \mathrm{kD}$ barley thylakoid polypeptides. In: Advances in Photosynthesis Research, C. Sybesma, ed., M. Nijhoff/Dr. W. Junk Publishers, The Hague, The Netherlands, Vol IV, 525-528 (1984)

16. HøYer-Hansen, G.: Monoclonal antibody to chlorophyll $a$-protein 1 in barley. In: Advances in Photosynthesis Research, C. Sybesma, ed., M. Nijhoff/ Dr W. Junk Publishers, The Hague, The Netherlands Vol III, 171-174 (1984)

17. Høyer-HANSEN, G. \& G. CASADORO: Unstable chloroplast ribosomes in the cold-sensitive barley mutant tigrina-o ${ }^{34}$. Carlsberg Res. Commun. 47, 103-118 (1982)

18. Høyer-Hansen, G., B.L. Møller, L.E.A. Henry \& G. CASADORO: Thylakoid polypeptide synthesis 
and assembly in wild-type and mutant barley. In: Cell Function and Differentiation. G. Akoyunoglou, A.E. Evangelopoulos, J. Georgatsos, G. Palaiologos, A. Trakatellis \& C.P. Tsiganos ed., A.R. Liss, Inc. Publ., New York, USA. Part B, 111-125 (1982)

19. Høyer-Hansen, G. \& D.J. Simpson: Changes in the polypeptide composition of internal membranes of barley plastids during greening. Carlsberg Res. Commun. 42, 379-389 (1977)

20. Kuwabara, T. \& N. Murata: Inactivation of photosynthetic oxygen evolution and concomitant release of three polypeptides in the photosystem II particles of spinach chloroplasts. Plant Cell Physiol. 23, 533-539 (1982)

21. KÖHLER, G. \& C. MiLSTEIN: Continuous cultures of fused cells secreting antibody of predefined specificity. Nature 256, 495-97 (1975)

22. LOWRY, O.H., N.J. ROSEBROUGH, A.L. FARR \& R.J. RANDALL: Protein measurements with the Folin phenol reagent. J. Biol. Chem. 193, 265-275(1951)

23. MACHOLd, O., \& G. HøYer-HaNSEN: Polypeptide composition of thylakoids from viridis and xantha mutants in barley. Carlsberg Res. Commun. 41, 359-366 (1976)

24. MAChOLD, O., D.J. Simpson \& B.L. Møller: Chlorophyll-proteins of thylakoids from wild-type and mutants of barley (Hordeum vulgare L.). Carlsberg Res. Commun. 44, 235-254 (1979)

25. Mendiola-Morgenthaler, L.R., J.J. MoRgenTHALER \& C.A. PRICE: Synthesis of coupling factor $\mathrm{CF}_{\text {, }}$ protein by isolated spinach chloroplasts. FEBS Lett. 62, 96-100 (1976)

26. Milstein, C.\& E. Lennox: The use of monoclonal antibody techniques in the study of developing cell surfaces. In: Current Topics in Developmental Biology. A.A. Moscona \& A. Monroy Eds., Academic Press, New York, Vol 14, 1-32 (1980)

27. MøLLER, B.L.\& P.B. HøJ: A thylakoid polypeptide involved in the reconstitution of photosynthetic oxygen evolution. Carlsberg Res. Commun. 48, 1'61-185 (1983)

28. MølleR, B.L., G. Høyer-HaNSEN \& R.G. Hiller: Functional identification of barley thylakoid polypeptides resolved by SDS-polyacrylamide gel electrophoresis. In: Photosynthesis III. Structure and molecular organisation of the photosynthetic apparatus. G. A koyunoglou ed., Balaban Int. Science Services, Philadelphia, Pa. pp. 245-256 (1981)

29. Møller, B.L., R.M. SMILlie \& G. HøYer-HANSEN: A photosystem I mutant in barley (Hordeum vulgare L.). Carlsberg Res. Commun. 45, 87-99 (1980)

30. NieLSEN, O.F.: Macromolecular physiology of plastids XII. Tigrina mutants in barley. Genetic, spectroscopic characterization. Hereditas 76, 269304 (1974)

31. Olive, J., F.A. Wollman, P. Bennoun \& M. RECOUVREUR: Ultrastructure-function relationship in Chlamydomonas reinhartii thylakoids, by means of a comparison between the wild type and the $F_{34}$ mutant which lacks the photosystem II reaction center. Molec. Biol. Rep. 5, 139-143 (1979)

32. OUCHTERLONY, $\mathrm{O}$ :: Antigen-antibody reactions in gels. Ark. Kemi, Mineral. och Geol. Vol. 26 B, 1-9 (1948)

33. OUCHTERLONY, O: Antigen-antibody reactions in gels. Acta Pathol. Microbiol. Scand. 32, 231 (1953)

34. Petrocellis, B.de, P. Siekevitz \& G.E. Palade: Changes in chemical composition of thylakoid membranes during greening of the $y-1$ mutant of Chlamydomonas reinhardi. J. Cell Biol. 44, 618634 (1970)

35. Schreier, M., G. Köhler, H. Hengartner, C. Berek, M. Trucco, L. Forni, T. Staemelin, J. STOCKER \& B. TAKACS: In: Hybridoma Techniques, EMBO, SKMB course, Basel pp. 1- 64 (1980)

36. Shulman, M., C.D. Wilde \& G. KöHLer: A better cell line for making hybridomas secreting specific antibodies. Nature 276, 269-270 (1978)

37. Simpson, D., G. Høyer-Hansen, N.-H. Chua \& D. VON WETTSTEIN: The use of gene mutants in barley to correlate thylakoid polypeptide composition with the structure of the photosynthetic membrane. Proc. Fourth Int. Congr. Photosyn. 1, 537548 (1977)

38. SimPSON, D.J. \& D. VON WetTSTEIN: Macromolecular physiology of plastids XIV. Viridis mutants in barley: Genetic, fluoroscopic and ultrastructural characterisation. Carlsberg Res. Commun. 45, 283-314 (1980)

39. Towbin, H., T. Staehelin \& J. GoRdon: Electrophoretic transfer of proteins from polyacrylamide gels to nitrocellulose sheets: Procedure and some applications. Proc. Natl. Acad. Sci. USA, 76, 4350-4354 (1979)

40. Westhoff, P., C. Jansson, L. Klein-Hitpass, R. BERzBORN, C. LARSSON \& S.G. BARTLETT: Intracellular coding sites of polypeptides associated with photosynthetic oxygen evolution of photosystem 11. Plant Mol. Biol. in press (1985)

41. WESTHOFF, P., N. NELSON, H. BÜNEMANN \& R.G. HERRMANN: Localization of genes for coupling factor subunits on the spinach plastid chromosome. Current Genetics 4, 109-120 (1981)

42. WettStein, D. von: Chloroplast and nucleus: Concerted interplay between genomes of different cell organelles. In: International Cell Biology 1980 1981. H.G. Schweiger, ed., pp 250-272 (1981) 
L.S. Hønberg: Probing barley mutants with a monoclonal antibody

43. Wettstein, D. von, B.L. Møller, G. Høyer-

HANSEN \& D.J. SIMPSON: Mutants in the analysis

of the photosynthetic membrane polypeptides. In:

Origin of Chloroplasts. J.A. Schiff, ed., Elsevier/

North-Holland, Biomedical Press, Amsterdam, pp

243-255 (1982)

Accepted by: H. KLENOw, E. LUND and S.O. ANDERSEN 